\title{
Effect of salinity on the vegetative characteristics, biomass and chemical content of red mangrove seedlings in the south of Iran
}

\author{
Efeito da salinidade nas características vegetativas, biomassa e conteúdo \\ químico de mudas de mangue vermelho no sul do Irã
}

\author{
Maryam Moslehi' (1), Tom Pypker² (1), Asghar Bijani ${ }^{3}$ (1) Akram Ahmadi $^{4}$ (1), \\ Mohammad Hossien Sadeghzade Hallaj ${ }^{5}$ (D) \\ ${ }^{1}$ Agricultural Research, Education and Extension Organization - AREEO, Bandar Abbas, Hormozgan, Iran \\ ${ }^{2}$ Thompson Rivers University - TRU, Kamloops, British Columbia, Canada \\ ${ }^{3}$ Islamic Azad University - IAU, Bandar Abbas, Hormozgan, Iran \\ ${ }^{4}$ Agricultural Research, Education and Extension Organization - AREEO, Gorgan, Golestan, Iran \\ ${ }^{5}$ Agricultural Research, Education and Extension Organization - AREEO, Tehran, Iran
}

\begin{abstract}
How to cite: Moslehi, M., Pypker, T., Bijani, A., Ahmadi, A., \& Hallaj, M. H. S. (2021). Effect of salinity on the vegetative characteristics, biomass and chemical content of red mangrove seedlings in the south of Iran. Scientia Forestalis, 49(132), e3748. https://doi.org/10.18671/scifor.v49n132.16
\end{abstract}

\begin{abstract}
We selected six months old seedlings of Rhizophora mucronata (Lam.) to evaluate the effect of different salinity on seedling growth, biomass and ion content in roots and leaves. We planted red mangrove propagules in plastic pots and irrigated them with freshwater (control), low salinity (EC: $8500 \mu \mathrm{m} . \mathrm{cm} ; 25 \%$ sea water+75\% freshwater), moderate salinity (EC: $29000 \mu \mathrm{m} . \mathrm{cm} ; 50 \%$ sea water+50\% freshwater) and high salinity (EC: $57000 \mu \mathrm{m} . \mathrm{cm} ; 100 \%$ sea water) for six months. Seedling grown at moderate salinity, had higher leaf number, collar diameter, height, root length, root dry weight, total dry mass weight and leaf area relative to seedlings grown at lower or higher concentrations. Concentrations of sodium and chloride ions in both leaves and roots increased with increasing salinity. Calcium, potassium and nitrogen in both leaves and roots were highest in the moderate treatment, followed by control, low salinity and high salinity treatments. All ions were higher in leaves, except for calcium, which was higher in roots. It can be concluded that the moderate salinity levels as it balances seedling quality with reduced demand for freshwater.
\end{abstract}

Keywords: Seawater; Rhizophora macronata; Khore-Azini; Seedling growth; Fresh and dry mass.

\begin{abstract}
Resumo
Selecionamos mudas de Rhizophora mucronata (Lam.) com seis meses de idade para avaliar o efeito de diferentes níveis de salinidade no crescimento das mudas, biomassa e teor de íons em raízes e folhas. Plantamos propágulos de mangue vermelho em vasos de plástico e os irrigamos com água doce (controle), baixa salinidade (CE: 8500 $\mu \mathrm{m} . \mathrm{cm}$ ), salinidade moderada (CE: $29000 \mu \mathrm{m} . \mathrm{cm}$ ) e alta salinidade (CE: $57000 \mu \mathrm{m} . \mathrm{cm}$ ) por seis meses. Mudas cultivadas em salinidade moderada apresentaram número de folhas, diâmetro do colo, altura, comprimento da raiz, massa seca da raiz, massa seca total e área foliar maiores em relação às mudas cultivadas em concentrações menores ou maiores. As concentrações de íons sódio e cloreto nas folhas e raízes aumentaram com o aumento da salinidade. Cálcio, potássio e nitrogênio em ambas as folhas e raízes foram maiores em salinidade moderada, seguidos pelos tratamentos controle, baixa salinidade e alta salinidade. Todos os íons foram maiores nas folhas, exceto o cálcio, que foi maior nas raízes. Pode-se concluir que o nível de salinidade de $50 \%$ é crítico para a sobrevivência das mudas, útil para o manejo da água em viveiros florestais.
\end{abstract}

Palavras-chave: Água do mar; Rhizophora macronata; Khore-Azini; Crescimento de mudas; Massa fresca e seca.

Financial support: None.

Conflict of interest: Nothing to declare.

Corresponding author: maryam.moslehi508@gmail.com

Received: 13 June 2021.

Accepted: 19 October 2021.

Editor: Mauro Valdir Schumacher

(c) This is an Open Access article distributed under the terms of the Creative Commons Attribution License, which permits unrestricted use,

c) distribution, and reproduction in any medium, provided the original work is properly cited. 


\section{INTRODUCTION}

Mangrove plants comprise a diverse group of woody plants species that are found in inter-tidal zones along tropical and subtropical coasts and have the unique ability to tolerate high concentration of salinity and low levels of soil aeration. Like many other halophytic species vegetative characteristics are improved under saline conditions (Flowers \& Colmer, 2008). Mangrove species have adapted to high salinity by decreasing their water and osmotic potential, thereby maintaining turgor (Khan et al., 2000). The ideal range of salinity differs for each species (Ball, 1988) and location (e.g. flooding regime and soil type) (Naidoo, 1987).

Several researchers have revealed the effect of different levels of salinity on the growth of mangrove species. For instance, Hoppe-Speer et al. (2011), Mahmood et al. (2014) and Chen $\&$ Ye (2014) reported maximum biomass occurred when salinity ranged from 0 to 10 practical salinity units (PSU) (Rhizophora mucronata at salinity 8 PSU). Aziz \& Khan (2001) investigated growth and physiological responses of Rhizophora mucronata and reported optimum growth of seedlings at $50 \%$ seawater. They also demonstrated with further increase in salinity, sodium and chloride were increased but potassium and calcium were decreased in plant organs. Khan \& Aziz (2001) showed optimal growth of mangrove seedling at 50\% sea water with sodium and chloride ions in the leaves increasing with the increasing salinity. Taffouo et al. (2007) reported that for Avicenna germinans, salinity affected leaf growth more than roots and stem and the height of the plants increased with salinity. Potassium and sodium in roots and leaves increased with increasing salinity. Previous studies reported the effects of salinity on the growth and biomass of mangrove plants (Basyuni et al., 2007; Nguyen et al., 2015). Kodikara et al. (2018) found that mangrove seedling under high salinity exhibited lower performance survival rate, mean growth rate, mean total leaf area and mean dry weight than those under low and moderate salinity.

Salinity is an important factor effecting the health, growth, productivity, and distribution of mangroves (Ball, 2002). Salinity has high spatial and temporal fluctuations because of salt and freshwater inputs, inundation, ground water seepages and evaporation (Aziz \& Khan, 2001). Maximum mangrove growth occurs under moderate salinity conditions, ranging from $10 \%$ to $50 \%$ sea water (Lin and Sternberg, 1995; Jayatissa et al., 2008; Flowers \& Colmer, 2015), with growth steadily decreasing at higher salinity (Naidoo, 1987). In addition, other research demonstrates that water with much lower salinity (between 10\% and 50\%) increased survival, growth, and productivity (Yakir \& Yechieli, 1995). However, correlation between salinity and maximum growth depends on the source population and site-specific growing conditions (Nguyen et al., 2015)

Natural habitats of mangrove forests in Iran are typically homogenous communities of Avicennia marina (Forssk.) Vierh. (area 25760 hectares). The exception in is in the south near Sirik port, were A. marina (Forssk.) Vierh. mixes with Rhizophora mucronata Lam. (Petrosian et al., 2014). In the past few decades, the health of mangrove forests has been negatively affected by direct and indirect deforestation and degradation. Mangroves in Iran may have been affected by tide changes, salinity, acidity, and nutrient levels (Farley et al., 2010).

In the south of Iran, the local people are interested in mangrove seedling production as way to support government afforestation and reforestation projects and to expand mangrove forests. In the south of Iran, R. mucronata occupies a small area and is threatened by climate change and frequent droughts. It is therefore necessary to encourage local people to produce more and stronger seedlings for afforestation and reforestation of R. mucronata. Mangroves in Iran are special and are located in arid regions of Iran. Therefore, when compared to most other mangroves around the world, $R$. mucronata in southern Iran are often shorter, wider with greater multi-branching (Moslehi et al., 2020). However, because southern Iran is arid, they lack sufficient fresh irrigation water for the propagation of $R$. mucronata in local nurseries. If saline water is to be used when propagating $R$. mucronata, increased knowledge regarding salinity tolerance of mangrove trees in southern Iran is needed to ensure strong nursery seedling production while also lowering water consumption. Therefore, the aim of this 
research is to i) investigate ion contents, biomass and growth rate of $R$. mucronata in response to a range of salinity ii) determine the best mix of freshwater and sea water (lower water consumption) that produces both a productive inland nursery while minimizing freshwater demand.

\section{MATERIAL AND METHODS}

\section{Seedlings}

Mature propagules were collected from several healthy $R$. mucronata trees from Khore-Azini (with longitude and latitude $26^{\circ}, 31^{\prime} 34.20$ " $\mathrm{N}$ and 57 degrees $6^{\prime}$ and $13.22^{\prime \prime} \mathrm{E}$ and mean annual humidity, temperature and precipitation, 57\%, 28.1 C and $226.9 \mathrm{~mm}$ ), Sirik port, South of Iran, and planted in plastic pots $(25 \times 10 \mathrm{~cm})$, filled with a sandy soil prepared by mixing loamy soil, sand and organic matter (degraded mangrove litter) in 1:1:1 ratio. Plants were grown in an open nursery under natural conditions (temperature, light and moisture). Propagules were irrigated twice a day with freshwater until two leaves appeared (Kodikara et al., 2018). Following the 2-leaf stage, the effect of four salinity levels treatments freshwater (control), low salinity ( $E C=8500 \mu \mathrm{m} . \mathrm{cm})$, moderate salinity ( $E C: 29000 \mu \mathrm{m} . \mathrm{cm}$ ) and high salinity (EC: $57000 \mu \mathrm{m} . \mathrm{cm})$ was tested on 60 seedlings ( $n=15$ per treatment) using a randomized design (Khan \& Aziz, 2001). Water for salinity treatments were prepared by mixing sea water and freshwater (control $=$ freshwater, low $=25 \%$ sea water $+75 \%$ freshwater, moderate $=50 \%$ sea water $+50 \%$ freshwater and high salinity $=100 \%$ sea water). To ensure surplus chlorine from the tap water was removed, water was kept in open containers for a few days prior to mixing. For each treatment there was a tank to use for irrigating pots (Kodikara et al., 2018). Initial stem diameter and height of each seedling was recorded.

After six months, vegetative characteristics (new leaf number, collar diameter, height, root length, leaf area) and biomass (fresh and dry weight of root, fresh and dry weight of stemleaf, total fresh weight, and total dry weight) were measured. Leaf area was measured with millimeter paper before drying. Mangrove seedlings were harvested and separated into stemleaf and roots weighted and dried. All leaves and roots were washed and dried in an oven at $75^{\circ}$ for $48 \mathrm{~h}$ (Basyuni et al., 2007).

The leaves and roots of five randomly selected seedlings were measured for ion content using dry and wet ash methods (Ehyaee \& Behbahanizadeh, 1993). To measure sodium, potassium, calcium, we dried and ground leaves and roots and then dissolved ground biomass in hydrochloric acid (2 molar) (Chapman \& Pratt, 1961). Sodium and potassium were analyzed using flame photometer (PFP7, Jenway, Staffordshire, UK) (Mountousis et al., 2009) and calcium analyzed using atomic absorption (UNICAM 919, Cambridge, UK) (Dewis \& Freitas, 1970). Chloride was measured by immersing the ground biomass in distilled water and then analyzing it by using an ion analyzer set (Jenway PCLM3). Nitrogen was measured by wet ash methods $\left(\mathrm{H}_{2} \mathrm{O}_{2}\right.$ \& $\left.\mathrm{H}_{2} \mathrm{SO}_{4}\right)$ and analyzed by the Kjeldahl method (Model Vab20, Germany) (Ehyaee \& Behbahanizadeh, 1993).

\section{Statistical analysis}

We checked for normality using Kolmogorov-Smirnov and Shapiro-Wilk tests. Except for new leaf numbers, all data was normal. Normal data were analyzed using a one-way analysis followed by Duncan's test for comparisons of all treatments and t- student for comparisons of ion contents between organs in each treatment $(\alpha=0.05)$. Non-normal data was analyzed using a Kruskal-Wallis $\mathrm{H}$ test and the mean of the treatments were compared against each other using a Mann-Whitney U. 


\section{RESULTS AND DISCUSSION}

\section{Growth rate and biomass of seedlings at different salinity}

Vegetative characteristics of red mangrove seedlings were generally higher at either moderate or low salinity (Figure 1). Collar diameter, plant height, root length and root dry length at moderate salinity were all greater than the other treatments Figure 1a-e). Low and moderate salinity produced higher stem and leaf fresh weight, total fresh biomass, and total dry mass relative to the control and high salinity treatments (Figure $1 \mathrm{f}, \mathrm{h}, \mathrm{i}$ ). The only treatment where the moderate treatment was lower than other treatments was stem and leaf dry weight, which as greater in the low treatment (Figure 1g). There was no difference in root fresh weight between treatments. New leaf number was higher at moderate, low and control treatments (4.2; 4; 3.93 respectively) relative to high salinity (Figure $1 \mathrm{k}$ ). In addition, the high salinity treatment reduced height growth and leaf area relative to the other treatments (Figure $1 \mathrm{~b}, \mathrm{j}$ ).
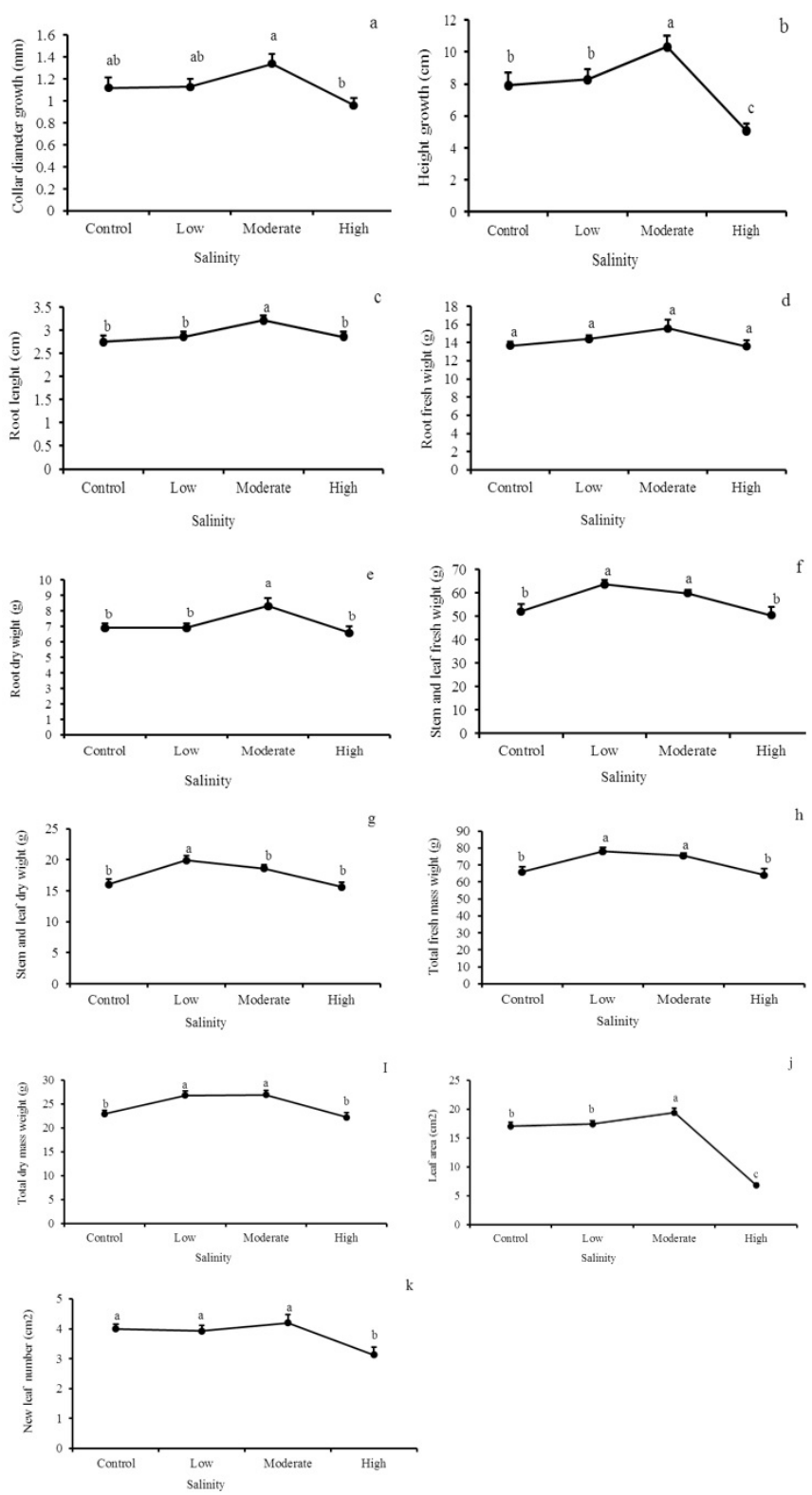

Figure 1: Effect of salinity on vegetative characteristics and biomass of Rhizophora mucronata seedlings $(p<0.05)$. Seedlings were subjected to four treatments (control, low $(E C=8500 \mu \mathrm{m} . \mathrm{cm})$, moderate (EC: $29000 \mu \mathrm{m} . \mathrm{cm}$ ) and high salinity (EC: $57000 \mu \mathrm{m} . \mathrm{cm})$ ). The control, low, moderate, and high salinity treatments were created by using $0,25 \%, 50 \%$ and $100 \%$ sea water, respectively. 
Similar to past research (Aziz \& Khan, 2001; Lin \& Sternberg, 1995; Jayatissa et al., 2008; Flowers \& Colmer, 2015; Kodikara et al., 2018), our study demonstrates that maximum growth of mangrove seedlings occurred at moderate salinity and that reduced growth occurred at high salinity. Root and leaf biomass were at a maximum when grown in water ranging from low to moderate salinity. Under low and moderate salinity conditions mangrove trees store more water to moderate the negative effect of salinity and increase survival. Hence, these conditions can improve seedling establishment and survival (Kodikara et al., 2018). However, once salinity passes a threshold, the excess salt affects plant growth because of more negative potentials, ion toxicity and nutrient deficiencies (Khan \& Aziz, 2001; Khan et al., 2000). For this reason, the mangrove seedlings grown with $100 \%$ sea water experienced significantly less growth. New leaf number and leaf area were highest at moderate salinity and reduced with increased salinity similar to the findings of Aziz \& Khan (2001), Nandy et al. (2007), Chen \& Ye (2014), and Kodikara et al. (2018). This is not surprising as plants respond to salt stress by reducing leaf area (Parida \& Das, 2005; Reef \& Lovelock, 2015). Halophytes, like mangrove, often shed leaves (Krauss et al., 2008) to remove excess salt (Siddique et al., 2017).

\section{Ion content of seedling root and leaf}

The concentration of sodium and chloride ions increased in both roots and leaves with increasing salt concentrations (Figure $2 \mathrm{a}, \mathrm{c}$ ). The highest sodium and chloride contents were observed in the leaves ( $\mathrm{Na}=12.4$ and $\mathrm{Cl}=19.14 \mathrm{mg} \mathrm{g}^{-1}$ of dry weight) and roots ( $\mathrm{Na}=10.82$ and $\mathrm{Cl}=16.84 \mathrm{mg} \mathrm{g}^{-1}$ of dry weight) at high salinity (Figure 2a, c). The lowest sodium and chloride concentrations were found in control; sodium and chloride concentrations were 7.36 and 13 $\mathrm{mg} \mathrm{g}^{-1}$ of dry weight in leaves and 6 and $11 \mathrm{mg} \mathrm{g}^{-1}$ of dry weight in roots, respectively.

Halophytes have a special ability to adjust tissue water potential to counter act the negative osmotic potential found in saline water (Khan \& Aziz, 2001). To adjust tissue water potential, halophytes accumulate ions in tissues to maintain turgor (Flowers et al., 1977; Khan \& Aziz, 2001). Our results showed that the concentration of sodium and chloride ions increased in leaves and roots as the salinity of the treatment water increased. Similar results were reported for Helianthus annuus and Lycopersicon esculentum seedlings (Agong et al., 2003; Hajer et al., 2006). Past research demonstrates that under high salinity conditions plants may reduce the toxic effects of sodium and chloride on tree organs (Taffouo et al., 2007) by increasing their solute concentration and cell elasticity (Rudulier, 2005; Taffouo, 2005). The changes in concentration and elasticity have been shown to lower the dry mass of the plant (Rudulier, 2005; Taffouo, 2005).

The impact of saltwater content on the potassium and nitrogen contents in leaves and roots varied with treatment (Figure $2 b, d, e)$. Potassium ion concentration in dry leaves were higher in the control and at moderate salinity (10.44 and $10.7 \mathrm{mg} \mathrm{g}^{-1}$ respectively) relative to the low and high treatments (9.24 and $9.1 \mathrm{mg} \mathrm{g}^{-1}$ respectively) (Figure 2b). The pattern was repeated in the roots, but the differences were not significant (Figure 2b). Nitrogen content in both leaves and roots increased from control to moderate salinity and then decreased at high salinity (Figure 2e). Nitrogen concentrations in leaves were highest in leaves at moderate treatment and lowest for roots in the high salinity treatment. There was no significant difference in calcium content in root or leaves across treatments (Figure 2d). 

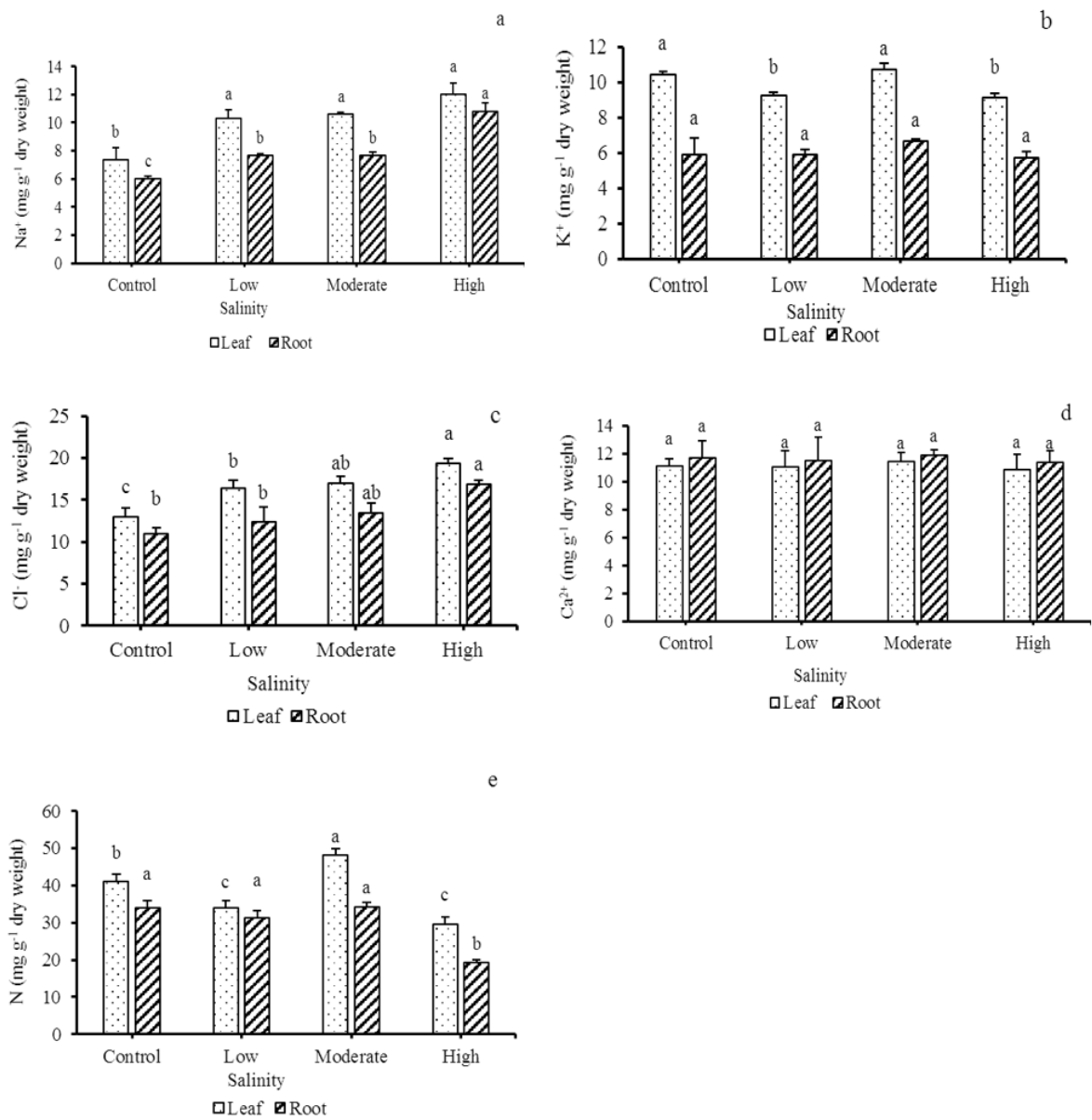

Figure 2: Mean ( \pm Standard error) of $\mathrm{Na}^{+}, \mathrm{K}^{+}, \mathrm{Ca}^{2+}, \mathrm{Cl}^{-}$and $\mathrm{N}$ of leaf and roots of Rhizophora mucronata seedlings grown under different sea water salinity. Seedlings were subjected to four treatments (control, low $(E C=8500 \mu \mathrm{m} . \mathrm{cm})$, moderate (EC: $29000 \mu \mathrm{m} . \mathrm{cm})$ and high salinity (EC: $57000 \mu \mathrm{m} . \mathrm{cm}))$. The control, low, moderate, and high salinity treatments were created using 0,25\%,50\% and 100\% sea water, respectively.

Values within each row with different superscripts are significantly different at $p<0.05$.

Halophytic plants, like the mangrove trees, have developed mechanisms to tolerate salinity stress. The present study showed that $R$. mucronata has better growth at moderate salinity likely because the plants prevent toxicity to occur through the high intracellular dilution (Taffouo et al., 2007). Dilution occurred in the mangrove plants because sodium and chloride increased while other ions decreased at high salinity. For example, potassium ions were greatest under moderate salinity. This likely occurred because moderate salinity stress results in increased succulence due to absorption of large quantities of water and potassium ions $\left(\mathrm{K}^{+}\right)$in leaves (Taffouo et al., 2007). The high accumulation of $\mathrm{K}^{+}$in leaves of $R$. mucronata at $50 \%$ salinity of sea water (moderate treatment) suggests that $\mathrm{K}^{+}$was responsible for osmotic adjustment in leaf cells (Taffouo et al., 2007). In addition, potassium concentrations in leaves were higher than those in roots at $0 \%$ sea water (control). Hence, higher concentrations of cations in halophyte plants may help decrease the negative effects of salinity (Taffouo et al., 2004).

All ions were higher in leaves, except for calcium, which was higher in roots (Figure 3). In the control treatment, potassium (10.44 $\mathrm{mg} \mathrm{g}^{-1}$ of dry weight) and nitrogen (41 $\mathrm{mg} \mathrm{g}^{-1}$ of dry weight) in leaves were higher than those in roots (Figure 3b, e). At low salinity, sodium and nitrogen content of leaves (10.32 and $34 \mathrm{mg} \mathrm{g}^{-1}$ of dry weight respectively) were higher than those in the roots (Figure 3a, e). Potassium, chloride and nitrogen (9.1, 19.4 and $29.6 \mathrm{mg} \mathrm{g}^{-1}$ of dry weight, respectively) were higher in leaves at high salinity $(p<0.05)$ (Figure $3 b, c, e)$. In the high salinity treatment, all cations, except for calcium, were higher in leaves than in roots (Figure 3). Calcium levels are important in determining the salt tolerance of a plant as calcium helps to protect plants as they grow. Calcium is important for the plant because it helps to 
preserve the structural and functional integrity of plant cell membranes, stabilize cell wall structures, and regulate ion transport and selectivity; controls ion-exchange behavior and cell wall enzyme activities (Hadi \& Karimi, 2012).
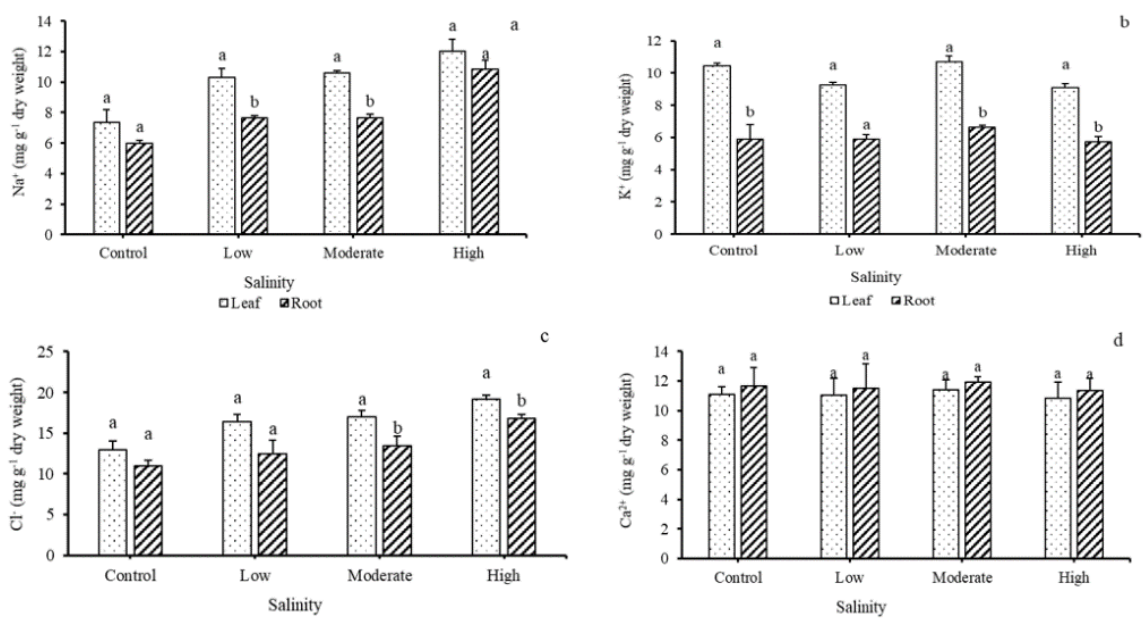

DLeaf ORoo

口Leaf ERoot

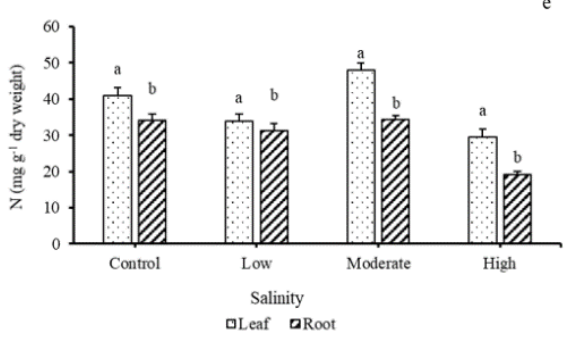

Figure 3: Effect of salinity on lon concentration $\left(\mathrm{Na}^{+}, \mathrm{K}^{+}, \mathrm{Ca}^{2+}, \mathrm{Cl}^{-}\right.$and $\left.\mathrm{N}\right)$ of seedling's organs $(\mathrm{p}<0.05)$. Seedlings were subjected to four treatments (control, low (EC=8500 $\mu \mathrm{m} . \mathrm{cm})$, moderate (EC: $29000 \mu \mathrm{m} . \mathrm{cm})$ and high salinity (EC: $57000 \mu \mathrm{m} . \mathrm{cm})$ ). The control, low, moderate, and high salinity treatments were created using $0,25 \%, 50 \%$ and $100 \%$ sea water, respectively.

\section{CONCLUSION}

We demonstrated that $R$. mucronata seedlings grown in an arid region had the best growth in moderate salinity (50\% sea water and EC: $29000 \mu \mathrm{m} . \mathrm{cm})$. Therefore, when growing these species in regions with limited water supply, moderate salinity and freshwater results in strong seedlings while also reducing the pressure on limited freshwater resources.

\section{REFERENCES}

Agong, S. G., Kingetsu, M., Yoshida, Y., Yazawa, S., \& Masuda, M. (2003). Response of tomato genotypes to induced salt stress. African Crop Science Journal, 11(2), 133-142. http://dx.doi.org/10.4314/acsj.v11i2.27526.

Ehyaee, M., \& Behbahanizadeh, A. A. (1993). Description of soil chemical analysis methods. Soil and Water Research Institute, 2(1024).

Aziz, I., \& Khan, M. A. (2001). Effect of seawater on the growth, ion content and water potential of Rhizophora mucronata Lam. Journal of Plant Research, 114(3), 369-373. http://dx.doi.org/10.1007/PL00013998.

Ball, M. (1988). Salinity tolerance in the mangroves Aegiceras corniculatum and Avicennia marina I. Water use in relation to growth, carbon partitioning, and salt balance. Australian Journal of Plant Physiology, 15, 447-464.

Ball, M. C. (2002). Interactive effects of salinity and irradiance ongrowth: implications for mangrove forest structure alongsalinity gradients. Trees (Berlin), 16(2-3), 126-139. http://dx.doi.org/10.1007/s00468-002-0169-3. 
Basyuni, M., Oku, H., Tsujimoto, E., Kinjo, K., Baba, S., \& Takara, K. (2007). Triterpene synthases from the Okinawan mangrove tribe, Rhizophoraceae. The FEBS Journal, 274(19), 5028-5042. PMid:17803686. http://dx.doi.org/10.1111/j.1742-4658.2007.06025.x.

Chapman, H. I., \& Pratt, P. F. (1961). Methods of analysis for soils, plants and waters. Berkeley: University Hall.

Chen, Y., \& Ye, Y. (2014). Effects of salinity and nutrient addition on mangrove Excoecaria agallocha. PLoS One, 9(4), e93337. PMid:24691495. http://dx.doi.org/10.1371/journal.pone.0093337.

Dewis, J., \& Freitas, F. (1970). Physical and chemical methods of soil and water analysis. Rome: FAO Soils Bulletin.

Farley, J., Batker, D., Torre, I., \& Hudspeth, T. (2010). Conserving mangrove ecosystems in the Philippines: transcending disciplinary and institutional borders. Environmental Management, 45(1), 39-51. PMid:19830480. http://dx.doi.org/10.1007/s00267-009-9379-4.

Flowers, J. T., \& Colmer, T. D. (2015). Plant salt tolerance: adaptations in halophytes. Annals of Botany, 115(3), 327-331. PMid:25844430. http://dx.doi.org/10.1093/aob/mcu267.

Flowers, T. J., \& Colmer, T. D. (2008). Salinity tolerance in halophytes. The New Phytologist, 179(4), 945963. PMid:18565144. http://dx.doi.org/10.1111/j.1469-8137.2008.02531.x.

Flowers, T. J., Troke, P. F., \& Yeo, A. R. (1977). The mechanism of salt tolerance in halophytes. Annual Review of Plant Physiology, 28(1), 89-121. http://dx.doi.org/10.1146/annurev.pp.28.060177.000513.

Hadi, M. R., \& Karimi, N. (2012). The role of calcium in plants' salt tolerance. Journal of Plant Nutrition 35(13), 2037-2054. http://dx.doi.org/10.1080/01904167.2012.717158.

Hajer, A. S., Malibari, A. A., Al-Zahrani, H. S., \& Almaghrabi, O. A. (2006). Responses of three tomato cultivars to see water salinity 1 . Effect of salinity on the seedling growth. African Journal of Biotechnology, 5(10), 855-861.

Hoppe-Speer, S. C., Adams, J. B., Rajkaran, A., \& Bailey, D. (2011). The response of the red mangrove Rhizophora mucronata Lam. to salinity and inundation in South Africa. Aquatic Botany, 95(2), 71-76. http://dx.doi.org/10.1016/j.aquabot.2011.03.006.

Jayatissa, L. P., Wickramasinghe, W. A. A. D. L., Dahdouh-Guebas, F., \& Huxham, M. (2008). Interspecific variation in response of mangrove seedlings to two contrasting salinities. International Review of Hydrobiology, 93(6), 700-710. http://dx.doi.org/10.1002/iroh.200711017.

Khan, A., \& Aziz, I. (2001). Salinity tolerance in some mangrove species from Pakistan. Wetlands Ecology and Management, 9, 219-223.

Khan, M. A., Ungar, I. A., \& Showalter, A. M. (2000). Effects of salinity on growth, water relations and ion accumulation of the subtropical perennial halophyte, Atriplex griffithii var. stocksii. Annals of Botany, 85(2), 225-232. http://dx.doi.org/10.1006/anbo.1999.1022.

Kodikara, K. A. S., Jayatissa, L. P., Huxham, M., Dahdouh-Guebas, F., \& Koedam, N. (2018). The effects of salinity on growth and survival of mangrove seedlings change with age. Acta Botanica Brasilica, 32(1), 37-46. http://dx.doi.org/10.1590/0102-33062017abb0100.

Krauss, K. W., Lovelock, C. E., McKee, K. L., Lopez-Hoffman, L., Ewe, S. M., \& Sousa, W. P. (2008). Environmental drivers in mangrove establishment and early development: a review. Aquatic Botany, 89(2), 105-127. http://dx.doi.org/10.1016/j.aquabot.2007.12.014.

Lin, G., \& Sternberg, L. (1995). Variation in propagule mass and its effect on carbon assimilation and seedling growth of red mangrove (Rhizophora mangle L.) in Florida, USA. Journal of Tropical Ecology، 11(1), 109-119. http://dx.doi.org/10.1017/S0266467400008464.

Mahmood, H., Saha, S., Siddique, M. R. H., \& Hasan, M. N. (2014). Salinity stress on growth, nutrients and carbon distribution in seedlings parts of Heritiera fomes. International Journal of Environmental Engineering, 1(4), 71-77.

Moslehi, M., Yaghoobzadeh, M., Bijani, A., \& Ahmadi, A. (2020). Measurement and estimation of specific leaf area, leaf dry mass and leaf area index of Rhizophora mucronata Lam. in Sirik mangrove forests. Majallah-i Jangal-i Iran, 12(3), 421-434.

Mountousis, I., Papanikolaou, K., Stanogias, G., Roukos, Ch., Chatzitheodoridis, F., \& Papazafiriou, A. (2009). Mineral content of the herbage material in pastures of Mt. Varnoudas NW Greece. Agronomy Research, 7(2), 837-846.

Naidoo, G. (1987). Effects of salinity and nitrogen on growth and plant water relations in the mangrove Avicennia marina (Forssk.) Vierh. The New Phytologist, 107(2), 317-325. PMid:33873850. http://dx.doi.org/10.1111/j.1469-8137.1987.tb00183.x.

Nandy, P., Das, S., Ghose, M., \& Spooner-Hart, R. (2007). Effects of salinity on photosynthesis, leaf anatomy, ion accumulation and photosynthetic nitrogen use efficiency in five Indian mangroves. Wetlands Ecology and Management, 15(4), 347-357. http://dx.doi.org/10.1007/s11273-007-9036-8. 
Nguyen, H., Stanton, E. D., Schmitz, N., Farquhar, D. G., \& Ball, C. M. (2015). Growth responses of the mangrove Avicennia marina to salinity: development and function of shoot hydraulic systems require saline conditions. Annals of Botany, 115(3), 397-407. PMid:25600273. http://dx.doi.org/10.1093/aob/mcu257.

Parida, A. K., \& Das, A. B. (2005). Salt tolerance and salinity effects on plants: a review. Ecotoxicology and Environmental Safety, 60(3), 324-349. PMid:15590011. http://dx.doi.org/10.1016/j.ecoenv.2004.06.010.

Petrosian, H., Ashrafi, S., Danehkar, A., \& Feghhi, J. (2014). Using logistic regression in identification climatology factors influencing the distribution of hormozgan province Avicennia Marina Forests. Iranian Journal of Natural Environment, 67(2), 135-144.

Reef, R., \& Lovelock, C. E. (2015). Regulation of water balance in mangroves. Annals of Botany, 115(3), 385-395. PMid:25157072. http://dx.doi.org/10.1093/aob/mcu174.

Rudulier, D. (2005). Osmoregulation in rhizobia: the key role of compatible solutes. Grain Legume, 42, 18-19.

Siddique, M. R. H., Saha, S., Salekin, S., \& Mahmood, H. (2017). Salinity strongly drives the survival, growth, leaf demography, and nutrient partitioning in seedlings of Xylocarpus granatum J. Konig. IForest, 10(5), 851-856. http://dx.doi.org/10.3832/ifor2382-010.

Taffouo, V. D. (2005). Variation de la réponse au stress salin chez cinq espèces de Légumineuses : étude des marqueurs physiologiques et biochimiques (Doctoral thesis). Université de Yaoundé I, Cameroun.

Taffouo, V. D., Fonkou, T., Knne, M., Wamba, O. F., \& Akoa, A. (2007). Salinity effect on seedling growth, water, sodium and potassium distributions in the mangrove species (Avicennia germinans $\mathrm{L}$. (Avicenniaceae)) in semi controlled condition. Agronimie Africine, 19(3), 263-270.

Taffouo, V. D., Kenne, M., Fokam Tasse, R., Fotsop, W. O., Fonkou, T., Vondo, Z., \& Akoa, A. (2004). Variation de la réponse au stress salin chez cinq espèces de Légumineuses. Agronimie Africine, 16, 33-44.

Yakir, D., \& Yechieli, Y. (1995). Plant invasion of newly exposed hypersaline Dead Sea shores. Nature, 374(6525), 803-805. http://dx.doi.org/10.1038/374803a0.

Author contributions: MM: Conceptualization, Funding acquisition, Methodology, Supervision, Writing - original draft,; TP: Writing - review \& editing, AB: Data curation, Formal analysis; AA: Writing - original draft, Writing review \& editing; MHSH: Writing - review. 